\title{
GCU
}

Glasgow Caledonian

University

University for the Common Good

\section{Diverting tampon taxes will not solve the issue of violence against women}

\section{Lorimer, Karen; Babchishin, Kelly}

Published in:

BMJ

DOI:

10.1136/bmj.i3952

Publication date:

2016

Document Version

Publisher's PDF, also known as Version of record

Link to publication in ResearchOnline

Citation for published version (Harvard):

Lorimer, K \& Babchishin, K 2016, 'Diverting tampon taxes will not solve the issue of violence against women', $B M J$, vol. 354. https://doi.org/10.1136/bmj.i3952

\section{General rights}

Copyright and moral rights for the publications made accessible in the public portal are retained by the authors and/or other copyright owners and it is a condition of accessing publications that users recognise and abide by the legal requirements associated with these rights.

Take down policy

If you believe that this document breaches copyright please view our takedown policy at https://edshare.gcu.ac.uk/id/eprint/5179 for details of how to contact us. 


\section{Diverting tampon taxes will not solve the issue of violence against women}

In the UK, tampons and other sanitary products are taxed at 5\%. Recently, European regulations have placed the power to tax feminine hygiene products on EU states ${ }^{1,2}$. This meant that the UK could change taxation rates for these products (of course, there is now uncertainty ahead for the UK post 'Brexit'). In 2015, the UK Chancellor, George Osborne, announced that he intended to direct $£ 15 \mathrm{~m}$ raised from this tax towards charities, such as SafeLives and Women's Aid. Although money to fund prevention programs and services is sorely needed, we believe that funding such programmes by taxing women on (necessary) feminine products is a superficial and insufficient solution to the issue of violence towards women, and perpetuates gendered price discrimination.

Such an approach perpetuates the detrimental notion that violence towards women is solely a woman's issue ${ }^{3}$; and it certainly does not cover the cost needed to fund violence against women programmes. Diverting taxes or a percentage of profits of products solely consumed by women for this purpose and framing it as 'corporate social responsibility', as the author suggested, is plainly asking women to help pay for their own domestic abuse and violence services. Taxing (necessary) feminine products also contributes to the economic burden of women across the world. Dubbed the 'pink tax', women already pay more for their personal hygiene products than men do for the equivalent products ${ }^{4}$.

Rather than taxing women, such taxes should be abolished. Instead, governments should promote a societal approach to ending violence towards women.

Dr Karen Lorimer

Senior Research Fellow

Glasgow Caledonian

University, Scotland

Karen.lorimer@gcu.ac.uk
Dr Kelly Babchishin

Banting Postdoctoral Fellow

The Royal's Institute of Mental Health

Research, Canada

Kelly.Babchishin@theroyal.ca

\section{References}

1. European Council. European Council conclusions 17-18/3/2016: Press release 143/16. Authors March 2016. [Available from

http://www.consilium.europa.eu/en/press/press-releases/2016/03/18-europe...

2. Seely A. Briefing paper: VA on sanitary protection (Number 01128). UK: House of Commons Library April 2016. Available from

http://researchbriefings.files.parliament.uk/documents/SN01128/SN01128.pdf

3. George R. Should the tampon tax be used to help domestic violence victims?

The Guardian November 2015 [Available from:

https://www.theguardian.com/commentisfree/2015/nov/26/tampon-tax-sanitar....

4. Shaw H. 'Pink tax' has women paying $43 \%$ more for their toileries than men'.

Financial post April 2016. [Available from

http://business.financialpost.com/news/retail-marketing/pink-tax-means-w... 